\title{
Synthesis, Characterization and Biological Activity of Schiff Base Metal Complexes Derived from 2, 4-Dihydroxyactophenone
}

\author{
RAJU ASHOKAN ${ }^{1}$, SARAVANAN SATHISHKUMAR ${ }^{1}$, \\ EKAMPARAM AKILA ${ }^{2}$ and RANGAPPAN RAJAVEL ${ }^{2 *}$ \\ ${ }^{1}$ Department of Chemistry, Periyar University, Salem-11, Tamilnadu, India \\ ${ }^{2}$ Department of Chemistry, Sri Saradha College for Women, Salem-16, Tamilnadu, India \\ drrajavelpu@gmail.com
}

Received 3 November 2016 / Accepted 30 November 2016

\begin{abstract}
A new series of $\mathrm{Co}(\mathrm{II}), \mathrm{Cu}(\mathrm{II}), \mathrm{Mn}(\mathrm{II})$ and $\mathrm{Ni}(\mathrm{II})$, complexes were prepared with ligand derived by condensation of 2,4-dihydroxyactophenone, $o$-phenylinediamine, anisaldehyde with $o$-phthalaldehyde. The Schiff base and its metal complexes were characterized on the basis of various spectroscopic investigation like IR, ${ }^{1} \mathrm{H}$ NMR, Photoluminescence and thermal analyses. The geometry of the complexes was confirmed by electronic spectra, magnetic moment measurements and ESR analysis. The $\mathrm{Co}(\mathrm{II}), \mathrm{Cu}(\mathrm{II}), \mathrm{Mn}$ (II) and $\mathrm{Ni}(\mathrm{II})$ complexes have also been studied for their plasmid (pUC18) DNA cleavage activity.
\end{abstract}

Keywords: Schiff base, 2,4-Dihydroxyactophenone, DNA cleavage, Anisaldehyde, $O$-phthalaldehyde

\section{Introduction}

Schiff base ligands have significant importance in chemistry; especially in the development of Schiff base complexes, because Schiff base ligands are potentially suitable of forming stable complexes with metal ions. Many Schiff base complexes show excellent catalytic activity in various reactions in the presence of moisture. Over the past few years, there has been much report on their applications in homogeneous and heterogeneous catalysis, hence the need for a review article highlighting the catalytic activity of Schiff base complexes ${ }^{1}$. The development of the field of bioinorganic chemistry has increased the interest in schiff base complexes, it has been recognized that many of these complexes may serve as models for biologically important species. Schiff base metal complexes have been studied extensively because of their attractive chemical and physical properties and their wide range of applications in numerous scientific areas. They play role in both synthetic and structural research, because of their preparative accessibility and structural diversity ${ }^{2}$. Schiff bases of o-phenylenediamine and its complexes have a variety of applications including biological, clinical and analytical. Present investigation deals with the syntheses, spectral characterization, 
thermal properties and DNA cleavage studies of series of $\mathrm{Co}(\mathrm{II}), \mathrm{Cu}(\mathrm{II}), \mathrm{Mn}$ (II) and $\mathrm{Ni}$ (II) metal complexes with four new Schiff base ligands derived from 2,4-dihydroxyactophenone, $o$-phenylinediamine, anisaldehyde with $o$-phthalaldehyde ${ }^{3}$ (Figure 1).<smiles>CC(=O)c1ccc(O)cc1O</smiles><smiles>Nc1ccccc1N</smiles><smiles>COc1ccc(C=O)cc1</smiles><smiles>O=Cc1ccccc1C=O</smiles>

2,4-Dihydroxyactophenone o-Phenylinediamine o-Phenylinediamine o-Phthalaldehyde Figure 1. Structure of compounds

\section{Experimental}

Schiff base ligand was prepared according to the literature procedures. Microbial studies were carried out according to reported procedures and DNA cleavage agarose gel electrophoresis by DNA binding studies by titration method.

\section{Synthesis of Schiff base $\left(\mathrm{H}_{2} \mathrm{~L}_{1}\right)$}

The Schiff base ligands were synthesized according to the general procedure. To an ethanolic solution of 2,4-dihydroxyactophenone $(2 \mathrm{mmol}), o$-phenylinediamine $(2 \mathrm{mmol})$ and anisaldehyde $(1 \mathrm{mmol})$ with $o$-phthalaldehyde $(2 \mathrm{mmol})$ was added in drop wise. The reaction mixture was kept on water bath for refluxion. It was stirred for $3 \mathrm{~h}$. Pale yellow color solid was separated and were filtered off, washed with $5 \mathrm{~mL}$ of cold ethanol and then dried in air. Yield: $73 \%$. M.p: $146-157{ }^{\circ} \mathrm{C}$. Anal.Calc. For $\mathrm{C}_{38} \mathrm{H}_{30} \mathrm{NO}_{6} \mathrm{Cl}_{2}$ : C, 67.21; H, 3.17; $\mathrm{N}, 8.26$. Found: C, 69.91; H, 3.51; N, 7.35. (\%). IR (KBr pellet, $\left.\mathrm{cm}^{-1}\right): 3305 \mathrm{v}(-\mathrm{OH}) ; 1691$ $v(-\mathrm{CH}=\mathrm{N}) ; 1259$ (-C-O). UV-Vis $\lambda_{\max }(\mathrm{nm}), 280,293\left(\pi \rightarrow \pi^{*}, \mathrm{n} \rightarrow \pi^{*}\right) . \mathrm{H}^{1} \mathrm{NMR}$ (DMSO, $\delta$ ppm): 6.1-7.3 ppm (m, Ar-H), 8.30 ppm (s, CH=N), 9.6 ppm (Ph-OH).

\section{Synthesis of complexes}

The ligand $\mathrm{L}_{1}$ and $\mathrm{L}_{2}$ was stirred with heating on water bath where upon a reddish brown solution was produced ${ }^{4-6}$. The contents were cooled to room temperature and a solution of metal acetate $(0.01 \mathrm{~mol})$ in DMF was added drop wise. The resulting mixture was stirred for $3 \mathrm{~h}$ with heating on a water bath. The product was filtered by suction, washed with ethanol and dried in vacuo ${ }^{7}$.

\section{Synthesis of metal complexes}

An ethanolic solution $(20 \mathrm{~mL})$ containing $\mathrm{L}_{1}(2,4$ dihydroxyactophenone $(2 \mathrm{mmol})$, o-phenylinediamine $(2 \mathrm{mmol}), \mathrm{L}_{2}$ anisaldehyde $(2 \mathrm{mM}), o$-phenylinediamine $(2 \mathrm{mmol})$ were added to a solution of metal acetates of $\mathrm{Co}(\mathrm{II}), \mathrm{Cu}(\mathrm{II}), \mathrm{Mn}$ (II) and $\mathrm{Ni}(\mathrm{II})(1 \mathrm{mM})$ in $25 \mathrm{~mL}$ of ethanol. The solution was refluxed for $3 \mathrm{~h}$ and then allowed to stand at room temperature for $24 \mathrm{~h}$. The product (Scheme 1) was filtered by suction and dried in vacuum ${ }^{8}$.

Physical data of $\mathrm{Cu}(\mathrm{II})\left(\mathrm{C}_{38} \mathrm{H}_{30} \mathrm{NO}_{6} \mathrm{Cl}_{2}\right)$

Yield: $65 \%$. M.p: $203-217{ }^{\circ} \mathrm{C}$. Anal.Calc. For $\mathrm{Cu}(\mathrm{II})\left(\mathrm{C}_{38} \mathrm{H}_{30} \mathrm{NO}_{6} \mathrm{Cl}_{2}\right): \mathrm{C}, 67.71 ; \mathrm{H}, 4.54 ; \mathrm{N}$, 7.81; Cu, 8.58. Found: C, 67.01; H, 4.73; N, 7.95; Cu, 8.94 (\%). IR (KBr pellet, $\left.\mathrm{cm}^{-1}\right): 1619$ 
$(-\mathrm{CH}=\mathrm{N}) ; 1216(-\mathrm{C}-\mathrm{O})$; $480(-\mathrm{M}-\mathrm{N}) ; 579(-\mathrm{M}-\mathrm{O}) . \mathrm{UV}-\mathrm{V}$ is $\lambda_{\max }(\mathrm{nm}), 290,301\left(\pi \rightarrow \pi^{*}\right.$, $\left.\mathrm{n} \rightarrow \pi^{*}, \mathrm{~L} \rightarrow \mathrm{MCT}\right) ; 520,575,625(\mathrm{~d} \rightarrow \mathrm{d}) . \mu_{\mathrm{eff}}(\mathrm{BM}): 1.74$.

Physical data of $\mathrm{Mn}(\mathrm{II})\left(\mathrm{C}_{38} \mathrm{H}_{30} \mathrm{NO}_{6} \mathrm{Cl}_{2}\right)$

Yield: 64\%. M.p: $218-225{ }^{\circ} \mathrm{C}$. Anal.Calc. For $\mathrm{Mn}(\mathrm{II})\left(\mathrm{C}_{38} \mathrm{H}_{30} \mathrm{NO}_{6} \mathrm{Cl}_{2}\right): \mathrm{C}, 68.35 ; \mathrm{H}, 4.38 ; \mathrm{N}$, 7.91; Mn, 7.69. Found: C, 67.59; H, 4.94; N, 7.79; Mn, $7.42(\%)$. IR (KBr pellet, $\left.\mathrm{cm}^{-1}\right)$ : $1782(-\mathrm{CH}=\mathrm{N}) ; 1603(-\mathrm{C}-\mathrm{O}) ; 463(-\mathrm{M}-\mathrm{N}) ; 596(-\mathrm{MO})$. UV-Vis $\lambda_{\max }(\mathrm{nm}), 281,317(\pi \rightarrow$ $\left.\pi^{*}, \mathrm{n} \rightarrow \pi^{*}, \mathrm{~L} \rightarrow \mathrm{MCT}\right) ; 647(\mathrm{~d} \rightarrow \mathrm{d}) . \mu_{\mathrm{eff}}(\mathrm{BM}): 5.73$.

Physical data of $\mathrm{Ni}(\mathrm{II})\left(\mathrm{C}_{38} \mathrm{H}_{30} \mathrm{NO}_{6} \mathrm{Cl}_{2}\right)$

Yield: $74 \%$. M.p: $241-259^{\circ}$ C. Anal.Calc. For $\mathrm{Ni}(\mathrm{II})\left(\mathrm{C}_{38} \mathrm{H}_{30} \mathrm{NO}_{6} \mathrm{Cl}_{2}\right): \mathrm{C}, 68.42 ; \mathrm{H}, 4.71 ; \mathrm{N}$, 7.92; Ni, 7.57. Found: C, 69.71; H, 4.69; N, 7.31; Ni, $7.73(\%)$. IR (KBr pellet, $\left.\mathrm{cm}^{-1}\right): 1623$ $(-\mathrm{CH}=\mathrm{N}) ; 1284(-\mathrm{C}-\mathrm{O}) ; 459(-\mathrm{M}-\mathrm{N}) ; 533 v(-\mathrm{M}-\mathrm{O}) . \mathrm{UV}-\mathrm{Vis} \lambda_{\max }(\mathrm{nm}), 280,385,465(\pi \rightarrow$ $\left.\pi^{*}, \mathrm{n} \rightarrow \pi^{*}, \mathrm{~L} \rightarrow \mathrm{MCT}\right) ; 513,555,618(\mathrm{~d} \rightarrow \mathrm{d}) . \mu_{\mathrm{eff}}(\mathrm{BM}): 3.08$.

\section{Physical data of $\mathrm{Co}(\mathrm{II})\left(\mathrm{C}_{38} \mathrm{H}_{30} \mathrm{NO}_{6} \mathrm{Cl}_{2}\right)$}

Yield: $69 \%$. M.p: $221-234{ }^{0} \mathrm{C}$. Anal.Calc. For $\mathrm{Co}(\mathrm{II})\left(\mathrm{C}_{38} \mathrm{H}_{30} \mathrm{NO}_{6} \mathrm{Cl}_{2}\right)$ : C, 67.21; H, 4.73; N, 7.91; Co, 7.59. Found: C, 66.31; H, 4.53; N, 7.96; Co, $7.94(\%)$. IR (KBr pellet, $\left.\mathrm{cm}^{-1}\right): 1729$ $(-\mathrm{CH}=\mathrm{N}) ; 1317(-\mathrm{C}-\mathrm{O})$; $497(-\mathrm{M}-\mathrm{N}) ; 510(-\mathrm{M}-\mathrm{O})$. UV-Vis $\lambda_{\max }(\mathrm{nm}), 285,320,\left(\pi \rightarrow \pi^{*}, \mathrm{n} \rightarrow\right.$ $\left.\pi^{*}, \mathrm{~L} \rightarrow \mathrm{MCT}\right) ; 510,563,609(\mathrm{~d} \rightarrow \mathrm{d}) . \mu_{\mathrm{eff}}(\mathrm{BM}): 4.81$.

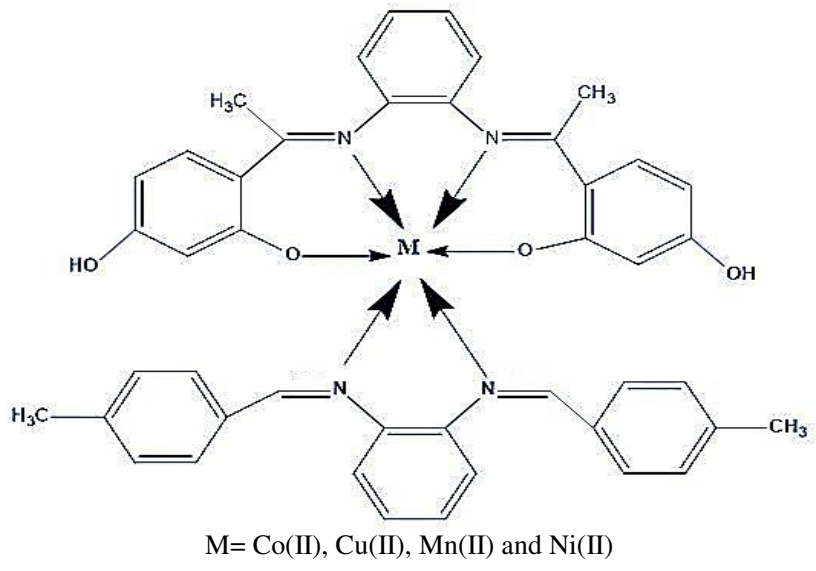

Scheme 1. Structure of Schiff Base metal(II) complexes

\section{Methodology for DNA cleavage study}

Preparation of culture media DNA cleavage experiment was done according to the literature. Nutrient broth $(10 \mathrm{~g} / \mathrm{L}$ of peptone, $5 \mathrm{~g} / \mathrm{L}$ of yeast extract, and $10 \mathrm{~g} / \mathrm{L}$ of $\mathrm{NaCl}$ ) was used for the culturing of Calf-thymus. After $50 \mathrm{~mL}$ of medium was prepared, it was autoclaved for $15 \mathrm{~min}$ at $121^{\circ} \mathrm{C}$ under $15 \mathrm{lb}$ of pressure $e^{9-11}$. The autoclaved medium was inoculated with the seed culture and incubated at $37{ }^{\circ} \mathrm{C}$ for $24 \mathrm{~h}$. DNA-Binding Experiments Electronic absorption spectroscopy has been widely employed to determine the binding characteristics of metal complexes with DNA ${ }^{12}$.

\section{Results and Discussion}

The interaction of $\mathrm{Co}(\mathrm{II}), \mathrm{Cu}(\mathrm{II}), \mathrm{Mn}(\mathrm{II})$ and $\mathrm{Ni}(\mathrm{II})$ metal acetates with ligand $\mathrm{L}_{1} \mathrm{~L}_{2}$ result in the formation of complexes have the general composition $\left[\mathrm{M}\left(\mathrm{L}_{1} \mathrm{~L}_{2}\right)\right]$. Where $\mathrm{M}=\mathrm{Co}(\mathrm{II})$, 
$\mathrm{Cu}(\mathrm{II}), \mathrm{Mn}(\mathrm{II})$ and $\mathrm{Ni}(\mathrm{II}), \mathrm{L}_{1}=2,4$ dihydroxyactophenone, $o$-phenylinediamine, $\mathrm{L}_{2}=o$-phenylinediamine and anisaldehyde.

\section{Thermogravimetric analysis}

The TGA curve of the $\mathrm{Cu}$ (II) complex $\mathrm{I}_{\mathrm{a}}$ is stable upto $120^{\circ} \mathrm{C}$. In the $\mathrm{Cu}$ (II) complex a weight loss of $12-14 \%$ was observed at a temperature range (Figure 2) of $244-249{ }^{\circ} \mathrm{C}$ corresponding to the removal of one acetate group. The complexes show a step weight loss of $27-29 \%$. In the temperature range $343-372{ }^{\circ} \mathrm{C}$ corresponding to the elimination of part of the Schiff base ligand groups from the coordination sphere of the complex. The final residue corresponds to $\mathrm{Cu}(\mathrm{II})>800{ }^{\circ} \mathrm{C}$.

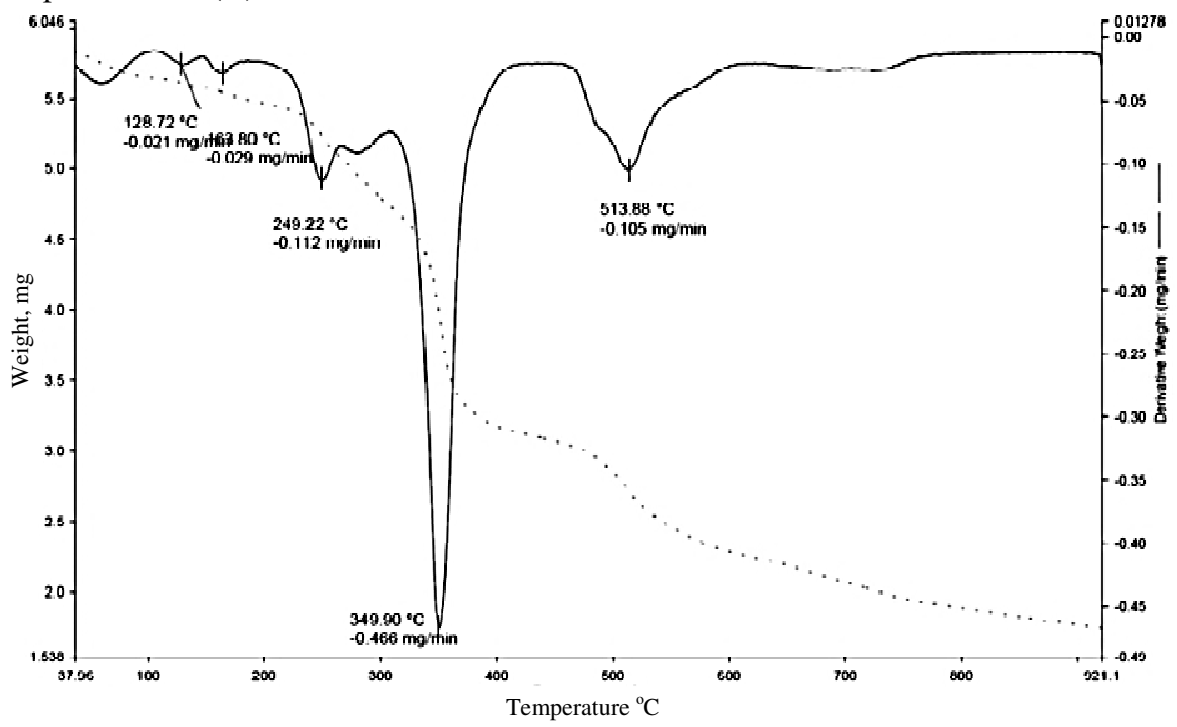

Figure 2. Thermogravimetric analysis of $\mathrm{Cu}(\mathrm{II}) \mathrm{L}_{1} \mathrm{~L}_{2}$ complexes

\section{Infrared spectra}

The IR spectra provide valuable information regarding the nature of functional group attached to the metal atom. In order to study the bonding mode of Schiff base to the metal complexes, the IR spectrum of the free ligand is compared with the spectra values of the complexes. A band at $1660 \mathrm{~cm}^{-1}$ in free Schiff base is due to the stretching vibration of azomethine $[v \mathrm{C}=\mathrm{N}]$. The shifting of this group to lower frequency $\left(1627-1688 \mathrm{~cm}^{-1}\right)$ in the metal complexes when compared to free ligand, suggests the coordination of metal ion through nitrogen of azomethine group ${ }^{13}$. New bands, which are not present in the (Figure 3) spectrum of ligand, appeared in the spectra of complexes in the range of $727-767 \mathrm{~cm}^{-1}$, corresponding to $v \mathrm{M}-\mathrm{N}$ and $623-662 \mathrm{~cm}^{-1}$ to $v \mathrm{M}-\mathrm{O}$ vibrations respectively. The appearance of vibrations $v(\mathrm{M}-\mathrm{N})$ and $v(\mathrm{M}-\mathrm{O})$ support the involvement of $\mathrm{N}$ and $\mathrm{O}$ atoms in complexation with metal ions. Therefore the IR spectral data indicate that the coordination sites of the metal ion are $-\mathrm{C}=\mathrm{N}$.

\section{${ }^{1} H$-NMR spectra analysis}

The ${ }^{1} \mathrm{H}$ NMR range of ligand $\left(\mathrm{Cu}(\mathrm{II}) \mathrm{L}_{1} \mathrm{~L}_{2}\right)$, (Figure 4) in DMSO solvent shows a particular signal at $(\delta=10.93 \mathrm{ppm})$ correspondent to two protons assigned to $(\mathrm{O}-\mathrm{H})$ group ${ }^{14}$. Two protons of $\left(\mathrm{C}_{5}-\mathrm{OH}, \mathrm{C}_{30}-\mathrm{OH}\right)$ group give the impression as a singlet signal at $(\delta=13.1 \mathrm{ppm})^{15-16}$. 
Two protons of $\left(\mathrm{N}=\mathrm{C}_{7}-\mathrm{H}, \mathrm{N}=\mathrm{C}_{28}-\mathrm{H}\right)$ imine group appears as a singlet signal at $(\delta=8.36 \mathrm{ppm})$. Two protons of $\left(\mathrm{N}=\mathrm{C}_{14}-\mathrm{H}, \mathrm{N}=\mathrm{C}_{21}-\mathrm{H}\right)$ imine group appears as a single signal at $(\delta=9.93$ $\mathrm{ppm})$. The multiple signal at $(\delta=6.33 \mathrm{ppm}),(7.23),(7.33),(7.46),(7.53),(7.63),(7.95) \mathrm{ppm}$ are due to aromatic hydrogen of carbon ${ }^{17,18}$.

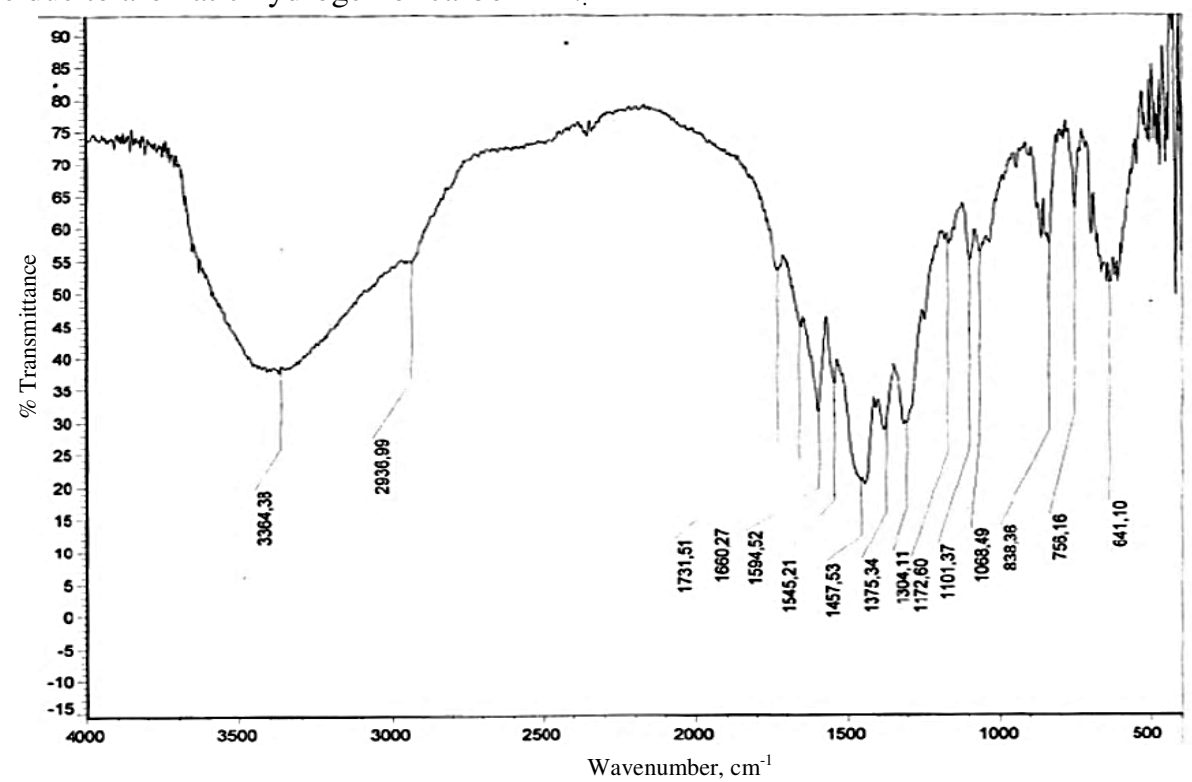

Figure 3. FTIR spectra for complex compounds of $\mathrm{Cu}(\mathrm{II}) \mathrm{L}_{1} \mathrm{~L}_{2}$

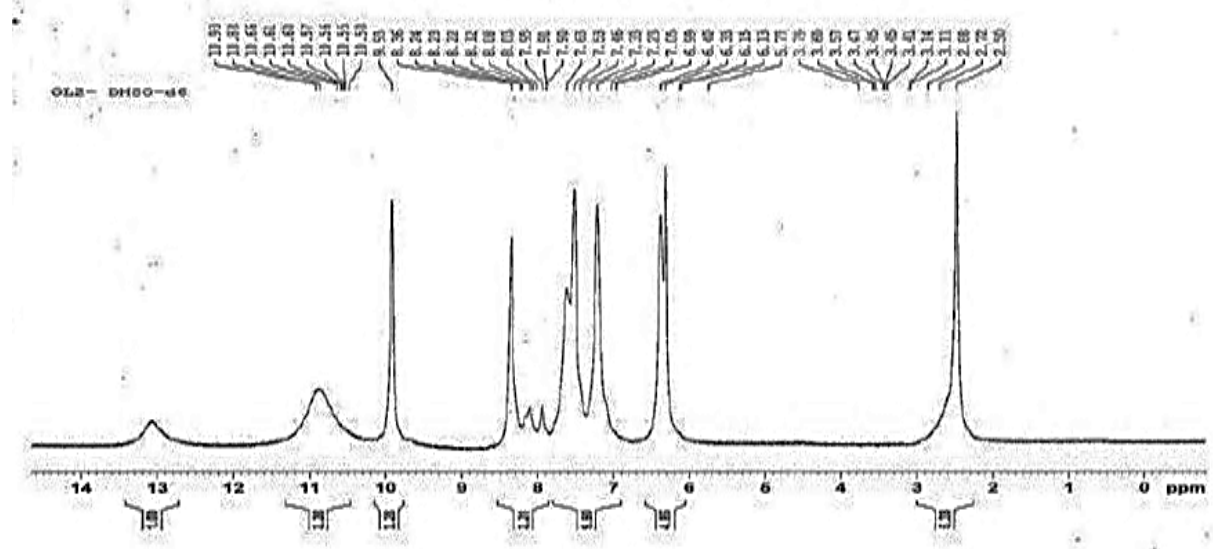

Figure 4. ${ }^{1} \mathrm{H}$ NMR spectrum of the ligand $\left(\mathrm{Cu}(\mathrm{II}) \mathrm{L}_{1} \mathrm{~L}_{2}\right)$

\section{Electronic spectra and magnetic moments}

The electronic absorption spectral data of the ligand and its metal complexes were recorded.The UV-Vis spectra of complexes show a band at $610 \mathrm{~nm}, 600 \mathrm{~nm}$ and $620 \mathrm{~nm}$ respectively, corresponding to $\mathrm{d}$-d transitions which are consistent with the octahedral geometry $^{19}$. In the band at $445 \mathrm{~nm}$ for 1,2 and $450 \mathrm{~nm}$ for 3 are due to $\mathrm{n} \rightarrow \pi^{*}$ transitions of azomethine $(\mathrm{C}=\mathrm{N})$ function of Schiff base and remaining bands in the UV region at $300 \mathrm{~nm}$ for 1,2 and $400 \mathrm{~nm}$ for 3 are due to $\pi \rightarrow \pi^{*}$ transitions of Schiff base respectively. 


\section{Photoluminescence spectra}

The photoluminescence spectra of Schiff base and its $\mathrm{Co}(\mathrm{II}), \mathrm{Cu}(\mathrm{II}), \mathrm{Mn}(\mathrm{II})$ and $\mathrm{Ni}(\mathrm{II})$ complexes were recorded in DMSO with an excitation wavelength of $265 \mathrm{~nm}$. The most enhancement in fluorescent intensity of metal complexes was observed in the case of $\mathrm{Cu}$ (II) complexes (Figure 5), with emission band observed at $497 \mathrm{~nm}$ as they are difficult to oxidize or reduce due to their stable $\mathrm{d}^{10}$ configuration. The emission bands for $\mathrm{Co}(\mathrm{II}), \mathrm{Cu}(\mathrm{II}), \mathrm{Mn}$ (II) and $\mathrm{Ni}(\mathrm{II})$ were observed at $471 \mathrm{~nm}, 406 \mathrm{~nm}$ and $403 \mathrm{~nm}$, respectively ${ }^{20}$. A weak fluorescent emission band at $370 \mathrm{~nm}$ was observed for Schiff base. The enhancement are in the order of $\mathrm{Cu}(\mathrm{II})>\mathrm{Co}$ (II) $>\mathrm{Mn}$ (II) $>\mathrm{Ni}$ (II) $>$ Schiff base. These enhancements in the fluorescent intensity of metal complexes show that Schiff base is one of the good chelating agents. Thus, Schiff base and metal complexes are fluorescent in nature and they open a way for the photochemical applications of the complexes ${ }^{21}$.

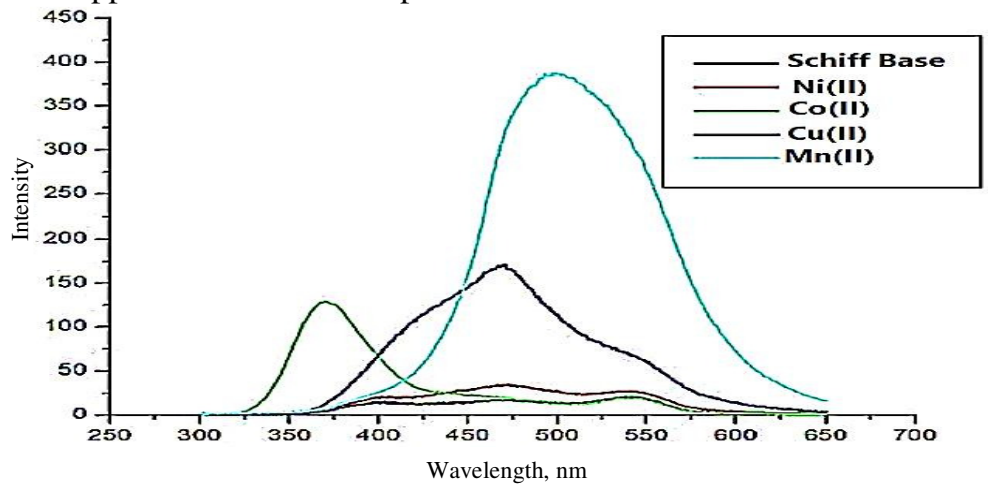

Figure 5. Photoluminescence spectra of Schiff base and its metal complexes

\section{ESR Spectra}

The X-band ESR spectra of complex $\mathrm{Cu}$ (II) was recorded in DMSO at room temperature. The spectra of copper complex exhibited anisotropic signals (Figure 6) with $\mathrm{g}$ values $\mathrm{g}_{\|}=$ 2.17 and $g_{\perp}=2.04$, and $g_{\|}=2.14$ and $g_{\perp}=2.03$ respectively, which is a characteristic of the axial symmetry ${ }^{22}$. The observed g-tensor values were $\mathrm{g}_{\|}(2.23)>\mathrm{g}_{\perp}$ (2.17) $>\mathrm{g}_{\mathrm{e}}$ (2.04) suggested the complex have octahedral geometry. An exchange coupling interaction between two $\mathrm{Cu}(\mathrm{II})$ ions was explained by Hathaway expression $\mathrm{G}=\left(\mathrm{g}_{\|}-2\right) /\left(\mathrm{g}_{\perp}-2\right)$. If the value $\mathrm{G}>4.0$, the exchange interaction is negligible and if $\mathrm{G}<4.0$, a considerable exchange coupling is [Figure 5] present in the complex.

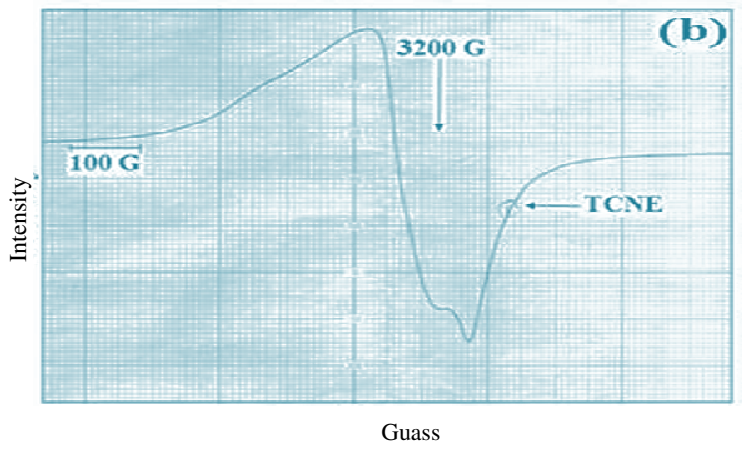

Figure 6. The ESR spectra of the $\left[\mathrm{Cu}(\mathrm{II}) \mathrm{L}_{1} \mathrm{~L}_{2}\right]$ 
In the present complex, the ' $G$ ' value (4.25) is $>4$ indicating that there is no interaction in the complex. In addition the absence of a half field signal at $1600 \mathrm{G}$ corresponding to DM $= \pm 2$ transitions indicates the absence of any $\mathrm{Cu}-\mathrm{Cu}$ interaction in the complex. Kivelson have shown that for an ionic environment $g_{\|}$is 2.3 or larger, but for a covalent environment $\mathrm{g}_{\|}$is less than 2.3. The $\mathrm{g}_{\|}$values for the present complex were 2.17 , indicating a significant degree of covalency in the metal-ligand bond ${ }^{23}$.

\section{Cyclic voltametry}

The copper complex (0.001 $\mathrm{M}$ in DMF) was scanned in the potential range of $-1.0 \mathrm{~V}$ to $1.0 \mathrm{~V}$ in deareated condition with scan rate $0.1 \mathrm{~V} / \mathrm{s}$. A cathodic peak observed in the voltammograms in the range $\mathrm{E}_{\mathrm{pc}}=0.15$ to $0.07 \mathrm{~V}$ evidences the reduction of metallic species, $\mathrm{Cu}(\mathrm{II}) \mathrm{L}_{1} \mathrm{~L}_{2}$. The reverse scan shows (Figure 7) two anodic peaks with potentials in the range $\mathrm{E}_{\mathrm{pa} 1}=-0.1$ to $-0.5 \mathrm{~V}$ and $\mathrm{E}_{\mathrm{pa} 2}=0.35$ to $0.68 \mathrm{~V}$ corresponding to the oxidation reactions $\mathrm{Cu}(\mathrm{II}) \mathrm{L}_{1} \mathrm{~L}_{2}$. The $\mathrm{Cu}(\mathrm{II})$ complex display a quasireversible cyclic voltammetric response which can be assigned to the $\mathrm{Cu}(\mathrm{II}) / \mathrm{Cu}(\mathrm{I})$ couple near $0.45 \mathrm{~V}$ in $\mathrm{DMF}^{24}$.

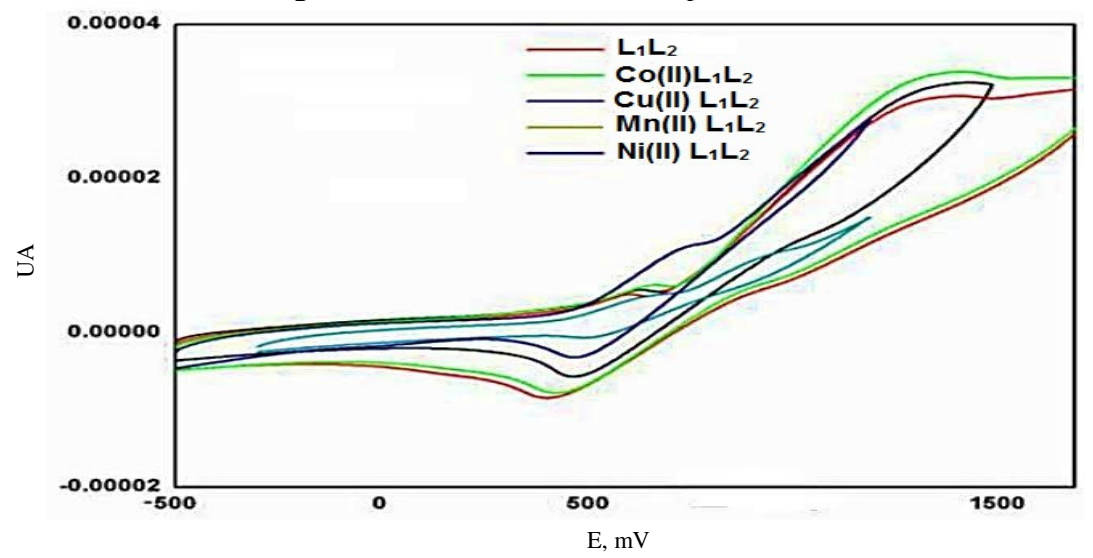

Figure 7. Cyclic voltammogram of synthesized complexes

\section{DNA Binding studies}

\section{DNA Binding - Electronic absorption study}

Electronic absorption spectroscopy transition metal complexes can bind to DNA through covalent bonding via replacement of a labile ligand of the complex by a nitrogen base of DNA such as guanine $\mathrm{N}_{7}$ or non-covalent interactions such as intercalation, electrostatic, or groove binding ${ }^{25}$. Electronic absorption spectroscopy is one of the most useful techniques in DNA binding studies since the observed changes in the spectra may give indication of the mode of interaction. The $\pi-\pi *$ intra ligand absorption bands with $\lambda_{\max }$ in the region 200-320 nm were used to monitor the interaction of compounds $L_{1}-C_{8}$ with double helical CT-DNA. The UV spectra have been recorded for a constant compound concentration in diverse [DNA]/[compound] $\operatorname{ratios}(r)$. The changes observed in the intra ligand transition of the compounds $\mathrm{L}_{1}-\mathrm{C}_{8}$ upon addition of CT-DNA solution in diverse $r$ values may reveal the existence of interaction between each compound and DNA and may indicate the possible mode of binding ${ }^{26}$.

Upon increasing the CT-DNA concentration, the UV spectra of compound-DNA solutions show a gradual decrease in the intensities of the absorption bands (hypochromism) 
(Figure 8) for all compounds without any apparent red shift ${ }^{27}$. The observed hypochromism may be attributed to stacking interaction between the aromatic chromophores of the free and bound ligands and DNA base pairs probably due to intercalation.

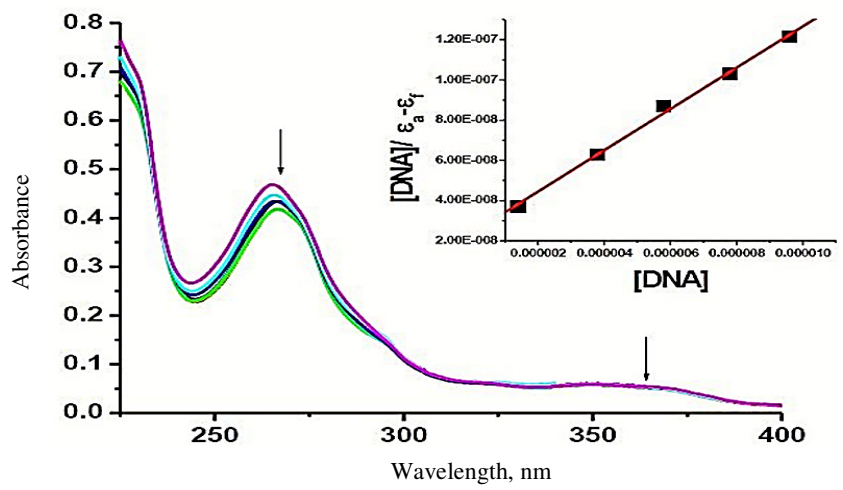

Figure 8. Electronic Absorption Spectroscopy complexes in $\mathrm{Cu}(\mathrm{II}) \mathrm{L}_{1}$

\section{DNA Cleavage studies}

DNA cleavage is measured by relaxation of supercoiled pUC18 DNA to nicked circular conformation and linear conformation. During electrophoresis process supercoiled DNA will migrate faster when compared with DNA in nicked and linear confirmations. Figure 9 illustrates the gel electrophoresis experiments showing the cleavage of plasmid pUC18 DNA induced by the metal complexes interest of the study.

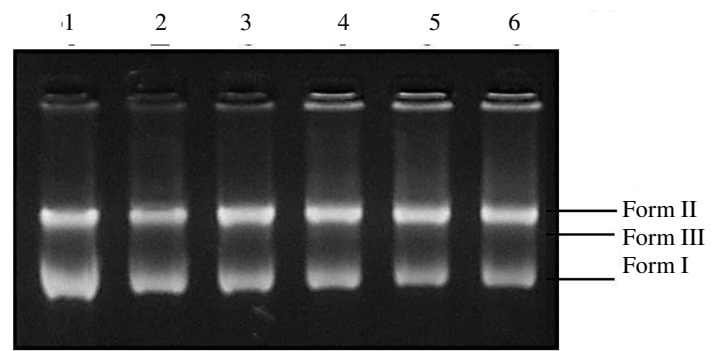

Figure 9. Changes in the Agarose gel electrophoresis pattern of pUC18, induced by $\mathrm{H}_{2} \mathrm{O}_{2}$ and metal complexes Lane 1 - pBR322 DNA - Control, Lane $2-\mathrm{DNA}+\mathrm{H}_{2} \mathrm{O}_{2}(1 \mathrm{mM})$, Lane 3 - DNA $+\mathrm{H}_{2} \mathrm{O}_{2}(1 \mathrm{mM})+\mathrm{Cu}$, Lane $4-\mathrm{DNA}+\mathrm{H}_{2} \mathrm{O}_{2}(1 \mathrm{mM})+\mathrm{Ni}$, Lane $5-\mathrm{DNA}+$ $\mathrm{H}_{2} \mathrm{O}_{2}(1 \mathrm{mM})+\mathrm{Mn}$, Lane $6-\mathrm{DNA}+\mathrm{H}_{2} \mathrm{O}_{2}(1 \mathrm{mM})+$ Co respectively

DNA with newly synthesized its $\mathrm{Cu}(\mathrm{II}), \mathrm{Co}(\mathrm{II}), \mathrm{Mn}(\mathrm{II})$ and $\mathrm{Ni}(\mathrm{II})$ complexes was studied using agarose gel electrophoresis method. Gel electrophoresis experiments were performed with complexes in the presence of $\mathrm{H}_{2} \mathrm{O}_{2}$ as an oxidant. The nuclease activity was greatly enhanced by the incorporation of metal ion in the respective co-polymer, it is evident from Figure 8, which shows that the complexes L ane 1, 2, 3,4,5 and 6 cleavage DNA more efficiently in the presence of oxidant, which may be due to the formation of hydroxyl free radicals. The production of hydroxyl free radical is due to the reaction between the metal complex and oxidant. These hydroxyl radicals participate in the oxidation of the deoxyribose moiety, followed by hydrolytic cleavage of the sugar phosphate backbone The difference was observed in the bands of the complexes compared to that of the control DNA. This shows that the control DNA alone does not show any apparent cleavage whereas the 
complexes show cleavage. However, the nature of reactive intermediates involved in the DNA cleavage by the complexes is not clear. These results indicate that the metal ions play an important role in the cleavage of isolated DNA. As the compound was observed to cleave the DNA, it can be concluded that the compound inhibits the growth of the pathogenic organism by cleaving the genome 51,52 . The studies reveal that complete cleavage of DNA was observed by $\mathrm{Cu}(\mathrm{II})$ and $\mathrm{Mn}(\mathrm{II})$ complexes and partial cleavage of DNA was observed by $\mathrm{Co}(\mathrm{II})$ and $\mathrm{Ni}(\mathrm{(II})$ complexes $^{28}$.

\section{Antibacterial study}

In vitro antimicrobial activity of Schiff base and its metal chelates was examined against two gram-positive bacteria (B. subtilis and $S$. aureus), two gram-negative bacteria (E. coli and K.Pneumoniae) by using agar well-diffusion method. Inhibition zone for gram-positive bacteria was found in the range of 10-23 mm, for gram-negative bacteria 10-20 mm and for yeasts $10-21 \mathrm{~mm}$. It has been observed that compounds $\mathrm{Cu}(\mathrm{II}) \mathrm{L}_{1} \mathrm{~L}_{2}$ were very effective against ${ }^{29}$ B. subtilis with zone of inhibition of $23 \mathrm{~mm}$ and $22 \mathrm{~mm}, S$. aureus with zone of inhibition of $15 \mathrm{~mm}$ and $17 \mathrm{~mm}, E$. coli with zone of inhibition of $20 \mathrm{~mm}$ and $19 \mathrm{~mm}$, K.Pneumoniae with zone of inhibition of $16 \mathrm{~mm}$ and $15 \mathrm{~mm}$, respectively (Figure 10). Thus metal complexes show enhanced biological activity as compared to ligand, and this can be better explained by the Overtone's concept of cell permeability and Tweedy's chelation theory.

According to Overtone's concept of cell permeability, the lipid membrane surrounding the cell favors the passage of only lipid-soluble material; therefore, lipid solubility is an important factor that controls the antimicrobial activity. On chelation, polarity of the metal ion is reduced to a greater extent due to the overlapping of the ligand orbital and partial sharing of the positive charge of the metal ion with donor groups ${ }^{30}$.

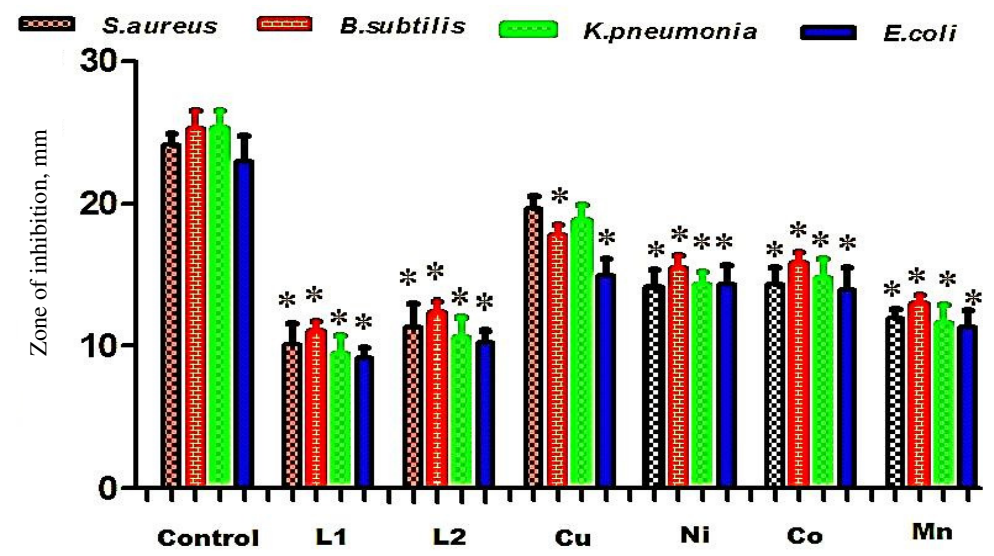

Figure 10. Biological evaluation of Schiff base and its metal complexes

Moreover, delocalization of the n-electrons over the whole chelate ring is increased and the lipophilicity of the complex is enhanced. The increased lipophilicity enhances the penetration of the complexes into the lipid membranes and blocks the metal binding sites in the enzymes of microorganisms.

\section{Conclusion}

Schiff base and metal complexes were synthesized and characterized by various physicochemical techniques like IR, ${ }^{1} \mathrm{H}$ NMR, ESR, electronic, magnetic moment, thermal, 
photoluminescence and cyclic voltammetry. With the help of aforementioned techniques around the $\mathrm{Co}(\mathrm{II}), \mathrm{Cu}(\mathrm{II}), \mathrm{Mn}(\mathrm{II})$ and $\mathrm{Ni}(\mathrm{II})$ complexes octahedral geometry around the $\mathrm{Cu}$ (II) complexes have been proposed. The DNA cleavage studies revealed that the metal complexes showed good efficiency towards DNA cleavage. Based on the analytical and spectral studies, we propose octahedral geometry to all the synthesized complexes. For instance, $\mathrm{Cu}(\mathrm{II}) \mathrm{L}_{1} \mathrm{~L}_{2}$ complexes show good activity.

\section{Acknowledgement}

The author would like to acknowledge valuable person Dr. Rangappan Rajavel for fruitful Discussions. The author is indebted to Supervisor for his encouragement and support. STIC Cochin, IIT Bombay and Progen lab are gratefully acknowledged for providing instrumental facilities. In addition, thanks are extended to the staff in Professor, Head of the Department, Department of Studies and Research in Chemistry, Periyar University, Salem, for encouragement and facilities.

\section{References}

1. Mounika K. Anupama B, Pragathi J and Gyanakumari C, J Sci Res., 2010, 2(3), 513524; DOI:10.3329/jsr.v2i3.4899

2. Kulkarni, Sangamesh Patil A and Prema Badami S, Int J Electrochem Sci., 2009, 4, 717-729.

3. Mashaly M M, Abd-Elwahabb Z H and Faheimb A A, J Chin Chem Soc., 2004, 51, 901-915.

4. Scozzafava A and Supuran C T, J Enzyme Inhibition Med Chem., 2002, 17(2), 117122; DOI: $10.1080 / 14756360290024218$

5. Al-Noor T H, Al-Jeboori A T and Aziz M R, Adv Phys Theor Appl., 2013, 18, 1-8.

6. May P M and Williams D R, Metal Ions Biological Systems 1981, 12, 256-268.

7. Sigman D S, Mazumder A and Perrin D M, Chem Rev., 1993, 93(6), 2295-2316; DOI:10.1021/cr00022a011

8. Sridhar S K and Ramesh A, Biol Pharm Bull., 2001, 24(10), 1149-1152; DOI:10.1248/bpb.24.1149

9. Raman N, Pothiraj K and Baskaran T, J Coord Chem., 2011, 64(22), 3900-3917; DOI:10.1080/00958972.2011.634005

10. Underhill A E and Billing, Nature, 1966, 210(), 834-835; DOI:10.1038/210834a0

11. Satyanarayana D N, University Press India, Limited, New Delhi, India, 2001, 297 301.

12. Danish M, Ali S, Badshah A, Mazhar M, Masood H, Malik A and Kehr G, Inorg Met Org Chem., 1997, 27(6), 863-865; DOI:10.1080/00945719708000234

13. Hernandes M M, Mckee M L, Keizer T S, Yeaswood B C and Atwood D A, J Chem Soc., Dalton Trans., 2002, 410, 410; DOI:10.1039/B106003C

14. Metzler C M, Cahill A and Metzler D E, J Am Chem Soc., 1980, 102(19), 60756082; DOI:10.1021/ja00539a017

15. Ganjali M R, Golmohammadi M, Yousefi M, Norouzi P, Salavati-Niasari M and Javanbakht M, Anal Sci., 2003, 19(2), 223; DOI:10.2116/analsci.19.223

16. Perry B F, Beezer, A E, Miles R J, Smith B W, Miller J and Nascimento M G, Microbois., 1988, 45, 181.

17. Verasundharam M M and Balachandran U N, Eur J Med Chem., 2013, 68, 244-252; DOI;10.1016/j.ejmech.2013.07.051

18. Raman N, Kulandaisamy A and Jeyasubramanian K, Indian J Chem., 2002, 41, 942-949. 
19. Pyle A M, Rehmann J P, Meshoyrer R, Kumar C V, Turro N J and Barton J K, J Am Chem Soc., 1989, 111(8), 3051-3058; DOI:10.1021/ja00190a046

20. Arunkumar A, Vijayababu M R, Kanagaraj P, Balasubramanian K, Aruldhas M M and Arunakaran J, Biolog Pharma Bull., 2005, 28(4), 740-743; DOI:10.1248/bpb.28.740

21. Reiss A, Florea S, Căproiu T H and Stănica N, Turkish J Chem., 2009, 33(6), 775-783.

22. Bisson-Boutelliez C, Fontanay S, Finance C and Kedzierewicz F, Pharm Sci Tech., 2010, 11(2), 574-581; DOI:10.1208/s12249-010-9412-1

23. Tarinc D, Muslu H, Cesme M, Golcu A, Tumer M and Ozkan S A, Current Anal Chem., 2013, 9, 319-332; DOI:10.2174/1573411011309020017

24. Reiss A, Căproiu T and Stănica N, Bull Chem Soc Ethiop., 2009, 23(1), 63-68; DOI:10.4314/bcse.v23i1.21299

25. Olea-Roman D, Villeda-Garcia J C, Colorado-Peralta R, Solano- Peralta A, Sanchez M, Hernandez- Ahuactzi I F and Castillo-blum S E, J Mex Chem Soc., 2013, 57(3), 230-238.

26. Xavier A J M, Raj M A and Marie J M, J Chem Pharm Res., 2012, 4(1), 669-672.

27. Mithun Roy, Ashis K Patra, Arindam Mukherjee, Munirathinam Nethaji, Akhil R and Chakravarty, Indian J Chem., 2007, 46, 227-237.

28. Vicini P, Geronikaki A, Incerti M, Busonera B, Poni G, Cabras C A and Colla P L Bioorg Med Chem., 2003, 11(22), 4785-4789; DOI:10.1016/S0968-0896(03)00493-0

29. Chohan Z H and Kausar S, Metal-Based Drugs, 2000, 7(1), 17-22; DOI:10.1080/14756360290024218

30. Parashar R K, Sharma R C, Kumar A and Mohan G, Inorg Chim Acta, 1988, 151(3), 201-208; DOI:10.1016/S0020-1693(00)83468-4 